\title{
Analysis of gender roles in tomato production in Municipal Area Council, Abuja, Nigeria
}

\author{
Ajibade, Y. E. ${ }^{*}$ Oyibo, F. O., Ameh, O. E. and Enimola, M. O. \\ Department of Agricultural Economics and Extension, Faculty of Agriculture, Kogi State University, P.M.B.1008, \\ Anyigba, Kogi State, Nigeria. \\ ${ }^{*}$ Corresponding author. Email: euniyetbade@yahoo.com
}

Copyright (@ 2021 Ajibade et al. This article remains permanently open access under the terms of the Creative Commons Attribution License 4.0, which permits unrestricted use, distribution, and reproduction in any medium, provided the original work is properly cited.

Received 9th November, 2020; Accepted 8th January, 2021

\begin{abstract}
This study analyzed gender roles in tomato production in Municipal Area Council, Abuja, Nigeria. The study described socio-economic characteristics of the tomato farmers, examined the activities carried out in tomato production, estimated costs and returns of tomato production, and identified constraints faced by tomato farmers in the study area. A multi-stage random sampling technique was adopted and a well structured questionnaire with scheduled interview were used to elicit information from one hundred and twenty respondents. Descriptive statistics, gross margin analysis and ztest were the analytical tools employed in this study. Results of the socio-economic characteristics of tomato farmers revealed that majority $(69.2 \%)$ of the respondents were male with a mean age of 45 years old. Results showed that male tomato farmers carried out land clearing $(51.8 \%)$ by personal labour while their female counterpart carried out land clearing

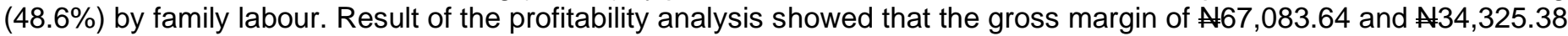
were realized for both male and female tomato farmers, respectively per cropping season. Tomato production in the study area was highly profitable for both male and female tomato farmers. The return on naira invested was $\mathrm{N1.99k}$ and $\mathrm{N1}$.67k for male and female tomato farmers respectively. Results showed that inadequate capital, lack of improved planting seeds, lack of contact with extension services among others were major constraints that affect tomato production in the study area. Therefore, female tomato farmers should be encouraged to cultivate improved crop varieties with strong seed coat and longer shelf life. The female tomato farmers could pool their resources together to purchase motorcycles or vehicles for easy movement of their produce from farm gates to market places in order to reduce high perishability of tomato fruits. Also, female tomato farmers should endeavor to use farm machinery and herbicides to solve the problems of inadequate labour supply and use of simple farm tools respectively, which do not encourage large scale production. The male tomato farmers should control pests and diseases infestation, package their tomato fruits to make them more attractive to consumers in order to earn higher market price.
\end{abstract}

Keywords: Abuja, gender, Municipal Area Council, production, roles, tomato.

\section{INTRODUCTION}

The term 'vegetable' refers to those plants and plant parts that are edible, especially leafy or fleshy parts that are usually eaten with staples as main courses or supplementary foods in cooked or raw forms. It is estimated that there are at least ten thousand $(10,000)$ plant species used as vegetables worldwide, although, only about fifty (50) are of great commercial value (ShingJy and Hsiao-Feng, 2013). Vegetables play very significant roles in human nutrition; they contain vitamins, minerals and chemical compounds that are essential for human health. For instance, vitamin A maintains eye health and strengthens the immune system, vitamin B helps convert food to energy, folate reduces the risk of some birth effects and helps prevent heart diseases. Vitamin $C$ increases the absorption of calcium and iron from other food. Vitamin $E$ is a powerful antioxidant that protects the cell from cancer causing agents. Dietary fibre helps move food through the digestive tract and lower blood cholesterol levels (Food and Agriculture Organization (FAO), 2016). The World Health Organization (WHO) places 
low vegetable intake sixth among its twenty risk factors of global human mortality, just behind better known killers such as tobacco use and high cholesterol (FAO, 2016). It is to this end that a minimum level of $400 \mathrm{~g}$ per head per day is recommended for the consumption of vegetables by the WHO. However, according to the FAO (2016), vegetable consumption per head per day in Nigeria is as low as $179 \mathrm{~g}$ compared to the recommended rate. $\mathrm{FAO} /$ WHO report had established that eating at least $400 \mathrm{~g}$ of fresh fruits and vegetables a day helps to alleviate micronutrient deficiencies and to prevent chronic diseases associated with unhealthy urban diets and lifestyles (FAO, 2012). However, daily consumption of vegetables is insufficient in Nigeria, despite its importance (Olaitan et al., 2018). Apart from its nutritional benefits, vegetables also serve as sources of employment for both the rural and urban dwellers directly or indirectly providing smallholder farmers with much higher income and more jobs per hectare than staple crops (FAO, 2016). According to Olatona et al. (2018), consumption of low fruits and vegetables is a major global risk factor for morbidity which is associated with micro-nutrient deficiencies and premature mortality.

Among different vegetables grown in Nigeria, tomato clearly stands out as the most important both in scale of production and level of consumption (Adejobi et al., 2011). It is an excellent source of phosphorus, iron and vitamin A, $B$ and $C$. Tomato contains small amounts of $B$ complex vitamins; thiamin, niacin and riboflavin (Dam et al., 2005). According to Mielgo-Ayuso et al. (2018), thiamin, niacin, riboflavin and vitamin $\mathrm{B} 6$ are essential ingredients that are mainly involved in energy metabolism; they prevent the occurrence of developmental abnormalities and chronic degenerative and neo-plastic diseases. It is grown for home consumption in the backyard gardens of almost every homestead across sub - Saharan Africa (Kale and Derek, 2020). It is a cash crop for both smallholders and medium - scale commercial farmers (Varela et al., 2003). Tomato is grown by most dry season market gardeners who regard it as the principal crop. In Nigeria, an annual total area of one million hectares is reportedly used for its cultivation and it makes up about 18 percent of the average daily consumption of vegetables in Nigerian homes (Lovendal Knowles, 2006). Nigeria is also ranked second largest producer of tomato in Africa and thirtieth largest in the world, producing 1.701 million tonnes of tomato annually at an average of 25 to 30 tonnes per hectare (FAO, 2010). Most other vegetables have restricted demand in Nigeria, but the demand for tomato is universal (FAO, 2010).

Women farmers particularly in rural areas of Nigeria have always worked and their labour plays a key role in the survival of millions of families (Adenugba and Raji, 2013). Most rural woman are the invisible farmers in Nigeria and form the backbone of rural development. The underlying facts that more than half of nigeria's food is produced by woman (Adenugba and Raji, 2013). Gender refers to the social attributes and opportunities associated with being male or female and the relationships between women and men (UNDP, 2009). It also includes the relationships between girls and boys, men and men as well as those between women and women. These attributes, opportunities and relationships are socially constructed. It is a culture relative term that changes with time and involves assignment of roles that changes from one culture to another or from one ethnic group to another. Gender roles are set of expectations as to what ought to be the appropriate behavior for men and women under particular circumstances (Idyorough, 2005).

The role that women play and their position in meeting the challenges of agricultural production and development are quite dominant and prominent. Their relevance and significance, therefore, cannot be overemphasized (Nnadozie and lbe, 2006; Rahman, 2008). Findings from a study financed by the United Nations Development Programme (UNDP) revealed that women make up some 60 to 80 percent of agricultural labour force in Nigeria (World Bank, 2003), depending on the region and they produce two-thirds of the food crops. Yet, in spite of these, widespread assumption that men - and not womenmake the key farm management decisions has prevailed. Sadly, female farmers in the country are among the voiceless, especially with respect to influencing agricultural policies. Such policies, which are aimed at increasing food security and food production, tend to either underestimate and/or totally ignore women's role in both production and the general decision-making process within the household. Various contributions of women to agricultural production in Nigeria have been variously described in the literature (Rahman, 2008; Amali, 2009; Damisa and Yohanna, 2007) but their role in decisionmaking process in agriculture has not been widely employed or at best, remains minimal (FAO, 2005; Rahman, 2008; Damisa and Yohanna, 2007).

Ironically, women are known to be more involved in agricultural activities than men in sub-Saharan African (SSA) countries, Nigeria inclusive. As much as 73 percent were involved in cash crops, arable and vegetable gardening, while post-harvest activities had 16 percent and agro-forestry had 15 percent (Abdullahi, 2012). Their involvement in agriculture in Nigeria has attracted greater attention in recent years. Reasons for their involvement are as many as are diverse. In some states, rural women have virtually taken over the production and processing of arable crops (Afolabi, 2008), being responsible for as much as 80 percent of the staple food items. Estimates of women's contribution to the production of food crops range from 30 percent in Sudan to 80 percent in Congo (FAO, 2005); contributing substantially to national agricultural production and food security, while being primarily responsible for the food crops. Thus, for the state to thrive in tomato production, it needs to achieve a high level of production which is essential for competitiveness and profitability. The failure of tomato farmers to meet demand 
in the state has raised concern over the inability of these farmers to increase tomato output, in view of the growing demand. Although, several studies have been carried out on analysis of resource use efficiency in tomato production in Nigeria (Ibitoye et al., 2015; Usman and Bakari, 2013; Obayelu et al., 2014); These studies do not look at the gender roles in tomato production in Municipal Area Council, Abuja. The essence of gender roles to this study is to sharpen the focus of advocacy for equitable integration of women and men in agricultural production to curb food crisis and sustain agricultural production in the country. In an effort to reach and engage the poor, we must recognize that some issues and constraints related to participation are gender-specific and stem from the fact that men and women play different roles, have different needs and face different challenges on a number of issues and at different levels. These views are supported by Ayoola and Odiaka (2004), they described gender as a socio-economic parameter that is useful in analyzing the roles, responsibilities, opportunities and constraints of both men and women along different ethnic. The following research questions were answered in this study:

1. What are the socio-economic characteristics of tomato farmers (male and female) in the study area?

2. What are the activities involved in by tomato farmers (male and female) in the study area?

3. What are the costs and returns of tomato farmers (male and female) in the study area?

Therefore, this study described the socio-economic characteristics of the respondents (that is, men and women), examined the activities carried out by them during production, estimated costs and returns incurred and accrued respectively by them and identified the constraints faced by the respondents.

\section{Hypothesis}

Ho: There is no significance difference between the costs and returns of male and female tomato farmers respectively.

\section{METHODOLOGY}

The study was carried out in Municipal Area Council of Abuja. Abuja Municipal Area Council (AMAC) is an area council in the Federal Capital Territory, with headquarters in Abuja as shown in Figure 1. AMAC is located west of Nasarawa State, with Kuje Area Council to the south, Gwagwalada Area Council to the east, and Bwari Area Council to the north. There are 12 wards in AMAC. The 12 wards of AMAC are: City Centre, Garki, Gui, Gwagwa, Gwarinpa, Jiwa, Kabusa, Karshi, Karu, Nyanya, Orozo, and Wuse. AMAC is located between latitude $8^{\circ} 40^{\prime}$ and $9^{\circ} 20^{\prime}$ north of the equator and longitude $6^{\circ} 40^{\prime}$ and $7^{\circ} 40^{\prime}$ east of the Greenwich meridian. AMAC has land area of 1,769 square kilometres, making it the biggest local government area council in the Federal Capital Territory. It has a population of 776,298 as at the 2006 national population census, AMAC is also the biggest local government area council by population in the Federal Capital Territory, and the second biggest in the entire country. AMAC was few decades ago predominantly inhabited by the Gbagyi, however, rapid urbanization spurred by the relocation of the seat of the government of the Federal Republic of Nigeria from Lagos to the council area in 1991 has turned it into a cosmopolitan metropolis, hosting people of different races and colours, as well as languages and tribes which include the usual suspects like the Igbo, the Hausa and the Yoruba. AMAC experiences three weather conditions annually. This includes a warm, humid rainy season and an extremely hot dry season. In between these seasons, there is a short period of harmattan accompanied by the north east trade wind, with the main feature of dust haze, intensified coldness and dryness. The rainy season begins from April and ends in October, when daytime temperatures reach 28 to 30 degrees and night time lows range around 22 to 23 degrees. In the dry season, daytime temperatures can reach 40 degrees and night time temperatures can drop to 12 degrees, resulting in chilly evenings. The major occupation of people in the study is farming while only few proportions of the residents engaged in white collar jobs and artisanship for example furniture, clothing, decorative arts, sculptures etc. AMAC is blessed with a mix of agricultural produce such as tubers and root crops such as (yams, cassava, maize and plantains), vegetables such as (tomatoes, onions, pumpkin, pepper and grain (sorghum, guinea corn and rice).

The population for this study comprises of tomato farmers (male and females) in Municipal area council of Abuja. A purposive sampling technique was used to select three wards from the Local Government Areas. The three wards selected were: Kabusa, Gwagwa, and Karshi. These wards were purposively selected based on high level of involvement in tomato production. Two communities from each of the wards were randomly selected to give a total of six communities for the study. Ten male and ten female farmers from each community were selected using random sampling techniques respectively, making a total sample size of one hundred and twenty respondents. Structured questionnaire with scheduled interview were used to elicit primary data from the respondents. Data were analysed using descriptive statistics, gross margin analysis and z-test analysis. The socio-economic characteristics of tomato farmers, activities carried out by respondents in tomato production and various constraints to tomato production were achieved using descriptive statistical tools such as frequency count, mean, mode and percentage. The costs and returns on tomato production were obtained through gross margin analysis and z-test analysis for hypothesis test. 


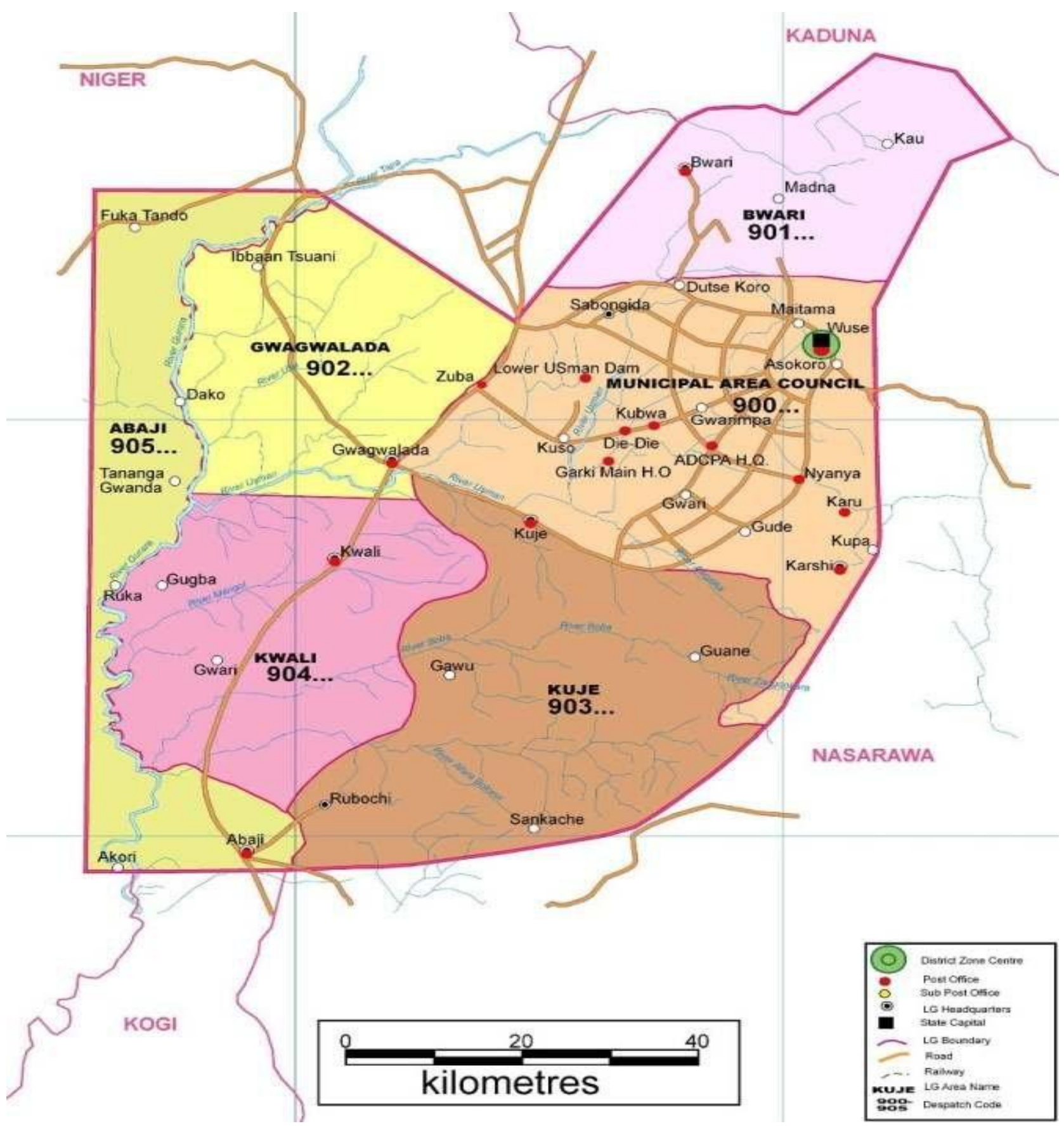

Figure 1. Map of Abuja Municipal Area Council, Abuja Source: Geograhic Information System, 2010.

Gross margin is the difference between the gross farm income (Gl) and the total variable cost (TVC). It is a useful planning tool in a situation where fixed capital is a negligible portion of farming enterprise as in the case of small scale subsistent agriculture (Abdullahi, 2012).

Gross margin analysis

$\mathrm{GM}=\mathrm{TR}-\mathrm{TVC}$
$\mathrm{NFI}=\mathrm{GM}-\mathrm{TFC}$ ii

Profit $(\pi)=$ TR - TC $\ldots \ldots \ldots \ldots \ldots \ldots \ldots \ldots \ldots$ iii

TC $=$ TFC + TVC $\ldots \ldots \ldots \ldots \ldots \ldots \ldots \ldots \ldots$ iv

The following profitability ratio was calculated:

$\mathrm{ROI}=(\mathrm{TR} / \mathrm{TC})-1 \ldots \ldots \ldots \ldots \ldots \ldots \ldots$

Where: $\mathrm{ROI}=$ Return on investment, $\mathrm{GM}=$ Gross Margin 
$(\mathrm{N} / \mathrm{Ha}), \mathrm{TR}=$ Total Revenue $(\mathrm{N} / \mathrm{Ha}), \mathrm{TVC}=$ Total Variable Costs $(\mathrm{N} / \mathrm{Ha}), \mathrm{TFC}=$ Total Fixed Cost $(\mathrm{N} / \mathrm{Ha}), \mathrm{TC}=$ Total Costs and NFI = Net Farm Income

\section{Z-test model specification}

Z-test is any statistical test for which the distribution of the test statistic can be approximated by a normally distribution (Vinay, 2015). Z test is used in testing significance difference, if the sample size is large enough to invoke the Central limit Theorem (usually $n \geq 30$ is a good rule of thumb) (Teshone, 2019). It was used to test whether there were significance differences in the costs and returns of male and female tomato farmers respectively.

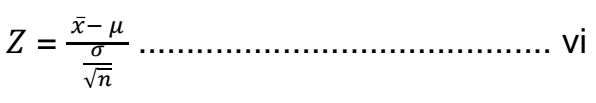

$Z$ Z Z-Test, $\bar{x}=$ Sample mean, $\mu=$ Population mean, $\sigma=$ Standard Deviation, $n=$ Number of observation.

\section{RESULTS AND DISCUSSION}

\section{Socio-economic characteristics of the respondents}

The distribution of respondents according to their socioeconomic characteristics is presented in Table 1. The results showed that about $41.0 \%$ of the male tomato farmers were in the age range of 40 to 49 years while $32.43 \%$ of the female farmers were in the age range of 30 to 39 years. The mean age of the male respondents was 47 years while the mean age of the female respondents was 44 years. By implication, tomato farmers in the study area were in their active age and were able to carry out various production activities involved in tomato production. This finding agrees with lbitoye et al. (2015) who reported that majority 82.5 percent of tomato farmers were within the age range of 41 to 60 years. Majority $(87.95 \%)$ of the male farmers were married while about $75.68 \%$ of female farmers were married. These showed that the respondents were married and responsible. This implies that the respondents have many dependants who could also serve as sources of family labour in tomato production. Thus, reducing the cost of hired labour and it could also be a plus in tomato productivity. This agrees with Sekumade and Toluwase (2014), who reported that $74.8 \%$ of the respondents in their study were married. Results of descriptive statistics showed that $54.22 \%$ of male tomato farmers and $51.35 \%$ of the female tomato farmers had 11 to 20 years of farming experience. The mean years of farming experience was 13 years. This implies that a greater number of the respondents have been involved in tomato production for a long time and could have learnt from their past mistakes and are able to correct them as well as anticipate and predict changes in climatic and economic factors. This may increase their level of efficiency, because the more experienced a farmer is, the more efficient he/she is and vice versa. These findings are in consonance with Maurice (2004), who reported a positive and significant relationship between farming experience and technical efficiency among farmers in Adamawa State.

The results further showed that in male headed households, $49.40 \%$ had household size of between 6 and 10 persons, while majority $51.35 \%$ of the female headed households had between 1 and 5 persons. This large number of household size could be an added advantage in terms of labour supply. This finding agrees with Saliu and Obasi (2011), who reported that a high percentage $(55.29 \%)$ of farmers had a household size range of between 6 and 15 . The results also showed that $39.76 \%$ of the male tomato farmers had no formal education while $43.24 \%$ of the female farmers had primary school education. It is evident from this finding that female respondents were more educated than their male counter parts in the study area. The level of education acquisition has an implication in the utilization or adoption of information on agriculture. This finding agrees with Issa et al. (2016), who reported that majority of the farmers $65.8 \%$ had primary education and the low literacy level of the male farmers also agreed with findings of Ndaghu et al. (2015), who discovered that $14.0 \%$ of the maize farmers had no formal education in their study. The implication is that education increases the ability to assess, interpret, and process information about a new technology, enhancing farmers' managerial skills including efficient use of agricultural inputs. The descriptive analysis further showed that majority $(75.90 \%)$ of male headed household and $78.38 \%$ of female headed household cultivated between 1 and 5 hectares of land per season. The mean number of hectares per household for male and female tomato farmers were 4.2 and 3.62 hectares respectively. It is evident from this finding that male tomato farmers have more farm land than their female counterparts in the study area. This agrees with the findings of Ibitoye et al. (2015), who reported that about 95.8 percent of tomato farmers in Kogi state cultivated tomato on an area of less than 5 hectares.

Results on extension services showed that $57.83 \%$ of male farmers affirmed to have had contact with extension agents while only about $32.43 \%$ of the female tomato farmers had contacts with extension agents. It is evident from this finding that male tomato farmers have more extension contacts than female in the study area. The increased frequency of extension agent visits is an opportunity to transfer skill, knowledge and information which facilitate farming operations. This is in agreement with Onu (2006) who reported that farmers who had access to extension adopted improved farming technologies than those who had no access to extension services.

The results also showed that majority $(93.98 \%)$ of male farmers and $89.19 \%$ of female farmers were members of farmers association while only $6.02 \%$ and $10.81 \%$ of male tomato farmers and female belong to cooperative societies 
Table 1. Socio-economic characteristics of tomato farmers.

\begin{tabular}{|c|c|c|c|c|c|c|}
\hline \multirow{2}{*}{ Variable } & \multicolumn{2}{|c|}{ Male } & \multicolumn{2}{|c|}{ Female } & \multicolumn{2}{|c|}{ Pooled } \\
\hline & Frequency & Percentage & Frequency & Percentage & Frequency & Percentage \\
\hline \multicolumn{7}{|l|}{ Age (Years) } \\
\hline $20-29$ & 5 & 6.02 & 4 & 10.81 & 9 & 7.50 \\
\hline 30-39 & 12 & 14.46 & 12 & 32.43 & 24 & 20.00 \\
\hline $40-49$ & 34 & 40.96 & 11 & 29.73 & 45 & 37.50 \\
\hline $50-59$ & 23 & 27.71 & 4 & 10.81 & 27 & 22.50 \\
\hline $70-79$ & 0 & 0 & 1 & 2.70 & 1 & 0.83 \\
\hline Total & 83 & 100 & 37 & 100 & 120 & 100 \\
\hline Mean & 45 & & 43 & & 45.01 & $10.56)^{\star}$ \\
\hline \multicolumn{7}{|c|}{ Marital status } \\
\hline Total & 83 & 100 & 37 & 100 & 120 & 100 \\
\hline \multicolumn{7}{|c|}{ Farming experience (years) } \\
\hline $1-10$ & 29 & 34.94 & 13 & 35.14 & 42 & 35.00 \\
\hline $11-20$ & 45 & 54.22 & 19 & 51.35 & 64 & 53.33 \\
\hline $21-30$ & 7 & 8.43 & 4 & 10.81 & 11 & 9.17 \\
\hline $31-40$ & 1 & 1.20 & 1 & 2.70 & 2 & 1.67 \\
\hline $41-50$ & 1 & 1.20 & 0 & 0.00 & 1 & 0.83 \\
\hline Total & 83 & 100 & 37 & 100 & 120 & 100.00 \\
\hline Mean & 13 & & 13 & & 13.78 & $7.45)^{\star}$ \\
\hline Total & 83 & 100 & 37 & 100 & 120 & 100.00 \\
\hline Mean & 6 & & 5 & & 5.89 & $2.57)^{\star}$ \\
\hline \multicolumn{7}{|c|}{ Level of education } \\
\hline Non-formal & 33 & 39.76 & 11 & 29.73 & 44 & 36.67 \\
\hline Primary & 23 & 27.71 & 16 & 43.24 & 39 & 32.5 \\
\hline Secondary & 20 & 24.1 & 8 & 21.62 & 28 & 23.33 \\
\hline Tertiary & 7 & 8.43 & 2 & 5.41 & 9 & 7.5 \\
\hline Total & 83 & 100 & 37 & 100 & 120 & 100 \\
\hline \multicolumn{7}{|l|}{ Farm size } \\
\hline $1-5$ & 63 & 75.90 & 29 & 78.38 & 92 & 76.67 \\
\hline $6-10$ & 17 & 20.48 & 8 & 21.62 & 25 & 20.83 \\
\hline $11-15$ & 2 & 2.41 & 0 & 0 & 2 & 1.67 \\
\hline $16-20$ & 1 & 1.20 & 0 & 0 & 1 & 0.83 \\
\hline Total & 83 & 100 & 37 & 100 & 120 & 100.00 \\
\hline Mean & 4.25 & & 3.62 & & & \\
\hline
\end{tabular}


Table 1. Contd.

\begin{tabular}{|c|c|c|c|c|c|c|}
\hline \multirow{2}{*}{ Variable } & \multicolumn{2}{|c|}{ Male } & \multicolumn{2}{|c|}{ Female } & \multicolumn{2}{|c|}{ Pooled } \\
\hline & Frequency & Percentage & Frequency & Percentage & Frequency & Percentage \\
\hline \multicolumn{7}{|l|}{ Extension service } \\
\hline Contact with extension services & 48 & 57.83 & 12 & 32.43 & 60 & 50 \\
\hline No extension contacts & 35 & 42.17 & 25 & 67.57 & 60 & 50 \\
\hline Total & 83 & 100 & 37 & 100 & 120 & 100 \\
\hline \multicolumn{7}{|l|}{ Association } \\
\hline Farmers Association & 78 & 93.98 & 33 & 89.19 & 111 & 92.5 \\
\hline Cooperative Society & 5 & 6.02 & 4 & 10.81 & 9 & 7.5 \\
\hline Total & 83 & 100 & 37 & 100 & 120 & 100 \\
\hline \multicolumn{7}{|l|}{ Occupation } \\
\hline Engaged in other occupation & 56 & 67.47 & 25 & 67.57 & 81 & 67.5 \\
\hline No other occupation & 27 & 32.53 & 12 & 32.43 & 39 & 32.5 \\
\hline Total & 83 & 100 & 37 & 100 & 120 & 100 \\
\hline \multicolumn{7}{|l|}{ Occupation } \\
\hline Trading & 71 & 85.54 & 28 & 75.68 & 99 & 82.5 \\
\hline Civil & 10 & 12.05 & 3 & 8.11 & 13 & 10.83 \\
\hline Artisanship & 2 & 2.41 & 6 & 16.22 & 8 & 6.67 \\
\hline Total & 83 & 100 & 37 & 100 & 120 & 100 \\
\hline \multicolumn{7}{|l|}{ Source of land } \\
\hline Purchase & 30 & 36.14 & 13 & 35.14 & 54 & 45 \\
\hline Rent & 9 & 10.84 & 4 & 10.81 & 13 & 10.83 \\
\hline Lease & 3 & 3.61 & 2 & 5.41 & 5 & 4.17 \\
\hline Inherited & 41 & 49.4 & 18 & 48.65 & 48 & 40 \\
\hline Total & 83 & 100 & 37 & 100 & 120 & 100 \\
\hline \multicolumn{7}{|l|}{ Source of capital } \\
\hline Personal Saving & 55 & 66.27 & 22 & 59.46 & 77 & 64.17 \\
\hline Friends and family & 19 & 22.89 & 10 & 27.03 & 29 & 24.17 \\
\hline Cooperative society & 1 & 1.2 & 4 & 10.81 & 5 & 4.17 \\
\hline Bank & 8 & 9.64 & 1 & 2.7 & 9 & 7.5 \\
\hline Total & 83 & 100 & 37 & 100 & 120 & 100 \\
\hline
\end{tabular}

Source: Field survey, 2019.

respectively. Social affiliation/relationship is a characteristic of rural communities and serves as an avenue of interaction and obtaining information on events in their locality. This is supported by the findings of Akinsanmi et al. (2005), who reported that cooperatives are vehicle for development since they provide informal credit to farmers. Members of the cooperative, ceteris paribus, are likely to perform better than non-members because of possible economies of scale. In addition, $67.47 \%$ of male tomato farmers and $67.57 \%$ of female farmers engaged in other activities aside farming. This implies that majority of the tomato farmers engaged in other income generating activities, to meet up other farming responsibilities. On other occupation engaged by tomato farmers, majority (85.54\%) of male tomato farmers and $75.68 \%$ of female tomato farmers engaged in trading. Participation in offfarm work was necessary so as to provide insurance against agricultural production risks. In the same assertion, Verter and Bečvářová (2014) argue that owing to the meager income from agricultural activities; some smallholder farmers are "pushed" to diversify into non-farm activities to complement their low earnings from farming activities. $49.4 \%$ of male tomato farmers and $48.65 \%$ of female tomato farmers cultivated land acquired through inheritance from their lineage for production respectively. The implication of this result is that majority of the farmers 
Table 2. Types of activities carried by tomato farmers.

\begin{tabular}{|c|c|c|c|c|c|c|}
\hline \multirow{2}{*}{ Activities } & \multicolumn{3}{|c|}{ Male } & \multicolumn{3}{|c|}{ Female } \\
\hline & PL & FL & $\mathrm{HL}$ & PL & FL & $\mathrm{HL}$ \\
\hline Land clearing & $43(51.8)$ & $20(24.1)$ & $20(24.1)$ & $12(32.4)$ & $18(48.6)$ & 7 (18.9) \\
\hline Staking & $26(31.3)$ & $40(48.2)$ & $17(20.5)$ & $6(16.2)$ & $20(54.1)$ & $11(29.7)$ \\
\hline Bed making & $20(24.1)$ & $46(55.4)$ & $17(20.5)$ & $9(24.3)$ & $18(48.6)$ & $10(27.0)$ \\
\hline Planting & $23(27.7)$ & $41(49.4)$ & $19(22.9)$ & 6 (16.2) & $24(64.9)$ & 7 (18.9) \\
\hline Fertilizer application & $18(21.7)$ & $45(54.2)$ & $20(24.1)$ & $6(16.2)$ & $21(56.8)$ & $10(27.0)$ \\
\hline Watering & $22(26.5)$ & $42(50.6)$ & $19(22.9)$ & $14(37.8)$ & $15(40.5)$ & $8(21.6)$ \\
\hline Weeding & $16(19.3)$ & $36(43.4)$ & $31(37.3)$ & $10(27.0)$ & $17(45.9)$ & $10(27.0)$ \\
\hline Thinning & $19(22.9)$ & $42(50.6)$ & $22(26.5)$ & $8(21.6)$ & $18(48.6)$ & $11(29.7)$ \\
\hline Supplying & $20(24.1)$ & $44(53.0)$ & $19(22.9)$ & $10(27.0)$ & $18(48.6)$ & $9(24.3)$ \\
\hline Harvesting & $22(26.5)$ & $41(49.4)$ & $20(24.1)$ & $10(27.0)$ & $18(48.6)$ & $9(24.3)$ \\
\hline Transporting of input & $16(19.3)$ & $52(62.7)$ & $15(18.1)$ & $12(32.4)$ & $19(51.4)$ & $6(16.2)$ \\
\hline Marketing & $27(32.5)$ & $39(47.0)$ & $17(20.5)$ & $12(32.4)$ & $15(40.5)$ & $10(27.0)$ \\
\hline
\end{tabular}

$\mathrm{PL}=$ Personal labour, FL = Family labour, HL = Hired labour (Source: Field Survey, 2019 values in parenthesis are percentages).

do not pay for land rent and therefore do not consider cost of land in production process. The result further revealed that, the right to the use of land in the study area is to a large extent customary. However, other system of land acquisition in the study area includes rent and purchase. Olukosi and Erhabor (2008) also discovered that in some subsistence farming communities, pieces of land were acquired through inheritance from one generation to another while others are either bought or rented. According to the findings, majority $(66.27 \%)$ of male tomato farmers and $59.46 \%$ of female sourced credit from personal savings. This implies that both male and female tomato farmers did not have access to formal credit sources. Thus, there would be limitation in their rate of expansion. According to Ndaghu et al. (2015), who reported that $11.7 \%$ of farmers in Safana local government area of Katsina State have access to credit facilities while majority $(88.3 \%)$ of farmers do not have access to credit facilities. However, access to credit is important to resource poor farmers to enable them access improved technologies along with their associated inputs like fertilizer.

\section{Activities carried out by respondents in tomato production}

Table 2 showed the results of activities carried out by the respondents in the study area. According to the results, male tomato farmers carried out land clearing $(51.8 \%)$ by personal labour while their female counterpart carried out land clearing (48.6\%) by family labour. Male and female tomato farmers in the study area used family labour to carry out the following activities: staking $(48.2 \%$ male, $54.1 \%$ female), bed making ( $55.4 \%$ male, $48.6 \%$ female), planting (49.4\% male, $64.9 \%$ female), fertilizer application (54.2\% male, $56.8 \%$ female), watering $(50.6 \%$ male,
$40.5 \%$ female), weeding ( $43.4 \%$ male, $45.9 \%$ female), thinning $(50.6 \%$ male, $48.6 \%$ female), supplying $(53.0 \%$ male, $48.6 \%$ female), harvesting $(49.4 \%$ male, $48.6 \%$ female), transporting inputs ( $62.7 \%$ male, $51.4 \%$ female) and marketing $(47.0 \%$ male, $40.5 \%$ female) was carried out by family labour. This implies that family labour plays important roles in the activities of tomato farmers on the farms. Since family labour are used by most of these farmers in the study area, it implies that the cultivation of tomato becomes more profitable since the farmers pay less for labour. Agriculture uses combination of male and female household labor, most of the family labor in agriculture is often offered by female and children (Shaw, 2004). Farm operations that required a lot of energy such as land clearing and land preparation were predominantly carried out by male, while female predominantly carry out relatively lighter operations in the farm which include; processing, harvesting and storage (Audu, 2009).

\section{Costs and returns of tomato farmers}

The costs and returns of tomato production are indicated in Table 3. The results show the list of variable costs that tomato farmers incurred, these includes; cost of seeds, cost of agrochemical, cost of fertilizer, cost of labour and other costs. The results showed that the cost of agrochemicals was the major variable costs incurred in tomato production by both male and female tomato farmers with an estimated amount of $\$ 11,730.72$ and A8,740.54per cropping season respectively. Male and female tomato farmers spent much on agrochemicals and there is significant difference at 1.0 percent level of significance between the amount spent by both genders. This implies that cost of agrochemicals is the highest variable cost incurred. This agrees with lbitoye et al. (2015), in their work on resource use efficiency among 
Table 3. Costs and returns of tomato farmers

\begin{tabular}{|c|c|c|c|c|}
\hline Item & Male (83) [In $]$ & Female (37) [In $\$$ ] & Pooled (120) [In $\#$ ] & Z-test \\
\hline \multicolumn{5}{|l|}{ (A) 1. Variable cost } \\
\hline a. seeds & 958.55 & 953.78 & 957.08 & 0.03 \\
\hline b. Agrochemical & $11,730.72$ & $8,740.54$ & $10,808.75$ & $2.46^{* * *}$ \\
\hline c. Fertilizer & $4,412.05$ & $3,565.68$ & $4,151.08$ & 0.81 \\
\hline d. Labour & $8,719.28$ & $8,375.14$ & $8,613.17$ & 0.30 \\
\hline e. Others & $5,558.80$ & $4,301.35$ & $5,171.08$ & 1.41 \\
\hline Total variable cost $(T V C)=(a+b+c+d+e)$ & $31,379.40$ & $25,936.49$ & $29,701.17$ & $2.22^{* *}$ \\
\hline \multicolumn{5}{|l|}{ 2. Fixed cost } \\
\hline f. Land renting & $16,180.72$ & $8,951.35$ & $13,951.67$ & 1.49 \\
\hline g. Depreciaton cost on fixed inputs & $1,933.43$ & $1,278.24$ & $1,731.42$ & 1.62 \\
\hline Total fixed cost $($ TFC $)=(f+g)$ & $18,114.16$ & $10,229.59$ & $15,683.08$ & 1.55 \\
\hline Total cost $(\mathrm{TC})=(\mathrm{TVC}+\mathrm{TFC})$ & $49,493.55$ & $36,166.08$ & $45,384.25$ & $2.46^{\star \star \star}$ \\
\hline \multicolumn{5}{|l|}{ (B) Return } \\
\hline h. Yield (No of baskets) & 24.72 & 18.35 & 22.76 & $2.18^{\star *}$ \\
\hline i. Price ( $\$ /$ basket) & $3,983.13$ & $3,283.78$ & $3,767.50$ & $3.08^{\star \star *}$ \\
\hline Total revenue $=\left(h^{\star} \mathbf{i}\right)$ & $98,463.04$ & $60,261.87$ & $85,742.02$ & $2.77^{\star \star \star}$ \\
\hline Gross margin $=($ TR - TVC) & $67,083.64$ & $34,325.38$ & $56,040.85$ & $2.34^{\star *}$ \\
\hline$(\mathrm{NFI})=\mathrm{GM}-\mathrm{TFC})$ & $48,969.48$ & $24,095.79$ & $40,357.77$ & 1.59 \\
\hline $\mathrm{ROI}=(\mathrm{TR} / \mathrm{TC})-1$ & 0.99 & 0.67 & 0.89 & 0.9 \\
\hline
\end{tabular}

${ }^{* * *} p<0.01 ;{ }^{* *} p<0.05 ;{ }^{*} p<0.1$.

Source: Field survey, 2019.

tomato farmers in Kogi State who reported that farmers spent more on pesticide.

The results showed that total variable cost of A31,379.40 and $\mathrm{N} 25,936.49$ per cropping season for male and female tomato farmers respectively. There is significant difference among male and female with respect to the total variable cost. The total cost of production for male and female tomato farmers were $\mathrm{N18,114.16}$ and N10,229.59 per cropping season respectively. This implies that male tomato farmers spent more on total cost than their female counterpart and this could be justified by the high number of male tomato farmers in the study area. Based on the computation per basket, the average basket of tomato was $70 \mathrm{~kg}$ and average price per basket was N3.983.13 for male tomato farmers and $\mathrm{N} 3,283.78$ for female tomato farmers. There was significant difference at 1.0 percent level of significance in the price per basket for both genders. This could be as a result of late arrival of female tomato farmers produce to the market, which might have affected the appearance of their tomato fruits with high level of perishability. The male tomato farmers might have access to better plant varieties than their female counterparts through the extension workers. The total revenue of $A 98,463.04$ and $A 60,261.87$ were realized for both male and female tomato farmers respectively. There is significant difference at one percent level of significance in the total revenue realized by both genders. The gross margin $\$ 67,083.64$ and $\$ 34,325.38$ were realized by both male and female tomato farmers with significant difference. This implies that male tomato farmers in the study area managed their crops more effectively and probably more efficiently than female tomato farmers who were faced with multiple activities at home, on the farm and other occupation. In view of this value of gross margin, generally, tomato production in the study area was highly profitable for both male and female tomato farmers. The return on money invested was $N 1.99 \mathrm{k}$ and $N 1.67 \mathrm{k}$ for male and female tomato farmers respectively. This implies that for every one naira invested by male tomato farmers in tomato production, $\$ 1.99 \mathrm{k}$ was realized, in like manner, for every one naira invested by female tomato farmers in tomato production, $N 1.67 \mathrm{k}$ was realized. Similarly, Sani and Haruna (2010) reported that the costs and returns analysis of vegetable crop production was economically viable.

\section{Constraints faced by tomato farmers}

According to this study, tomato farmers were faced with diverse problems in the study area. A major problem identified by male $(69.9 \%)$ and female $(94.6 \%)$ tomato farmers in the study area was inadequate capital (Table 4). Access to credit in farming plays an important role in 
Table 4. Constraints faced by tomato farmers.

\begin{tabular}{lcccc}
\hline \multirow{2}{*}{ Constraints } & \multicolumn{2}{c}{ Male } & \multicolumn{2}{c}{ Female } \\
\cline { 2 - 5 } & Frequency $\left(^{*}\right)$ & Percentage & Frequency $\left(^{*}\right)$ & Percentage \\
\hline Inadequate Capital & 58 & 69.9 & 35 & 94.6 \\
Lack of improved planting seeds & 67 & 80.7 & 34 & 91.9 \\
Lack of contact with extension services & 61 & 73.5 & 28 & 75.7 \\
Lack of knowledge about weather forecasting & 58 & 69.9 & 23 & 62.2 \\
High cost of labour & 48 & 57.8 & 33 & 89.2 \\
High cost of transportation & 48 & 57.8 & 32 & 86.5 \\
Use of local tools for farm operations & 53 & 63.9 & 27 & 73.0 \\
High Pest and disease infestation & 55 & 66.3 & 23 & 62.2 \\
Low market price & 53 & 63.9 & 22 & 59.5 \\
High perishability of the commodity & 45 & 54.2 & 26 & 70.0 \\
Inadequate herbicides/pesticides & 49 & 59.0 & 21 & 56.8 \\
Inadequate market facilities & 41 & 49.4 & 21 & 56.8 \\
Lack of Storage facilities & 37 & 44.6 & 24 & 64.9 \\
Excessive rainfall & 40 & 48.2 & 16 & 43.2 \\
Lack of Grading facility & 38 & 45.8 & 13 & 35.1 \\
Poor soil fertility & 43 & 51.8 & 8 & 21.6 \\
Health challenges & 39 & 47.0 & 11 & 29.7 \\
\hline
\end{tabular}

*Multiple response allowed.

Source: Field survey, 2019.

increasing productivity. Tomato farmers in the study area do not have adequate access to fund to expand the scale of tomato production. Production costs such as cost of purchasing and other related costs were mainly funded from individual savings. Lack of improved planting seeds was another problem identified by both male $(80.7 \%)$ and female $(91.9 \%)$ tomato farmers in the study area. This is in line with the findings of Adegbite et al. (2010), who discovered the problem of lack of seed quality research such as protein, oil, carbohydrate and anti-nutritional factors. Lack of contact with extension services was a problem identified by both male (73.5\%) and female $(75.7 \%)$ tomato farmers in the study area. Poor extension services confirm the report by Tiwani (2010) that one of the major constraints of farmers was poor access to extension services. Inadequate extension contact can restrict farmers from becoming aware and subsequently adopting new innovation. Farmers who have contact with extension agents often tend to adopt new technological practices faster and use the information to build up their standard of living, while those who have less contact with extension agent are less likely to adopt new technological practices and this could be due to the fact that farmers are conservative to certain ways of doing things due to their primitive knowledge and the tendency to adopt the innovation becomes difficult. Lack of knowledge about weather forecasting was another problem identified by both male $(69.9 \%)$ and female $(62.2 \%)$ tomato farmers in the study area. This finding agrees with Ozor and Nnaji (2010) who stated that poor climate change information and farmers lack of access to weather forecast technologies were major barriers to climate change adaptation among farming household in Nigeria.

High cost of labour (57.8\% for male) and $(89.2 \%$ for female) implies that female tomato farmers, due to their multiple responsibilities of child bearing, child caring, regular household chores among others have to pay more for hired labour for their farming activities. High cost of transportation $(57.8 \%)(86.5 \%)$ and use of local tools for farm operations $(63.9 \%)(73.0 \%)$ were serious problems identified by both male and female tomato farmers in the study area. However, female tomato farmers encountered more problems in these regards than their male counterparts. Most female tomato farmers have no personal means of conveying their tomato fruits from farm gates to the markets, they depend on commercial means of transportation unlike most male tomato farmers who personally owned motorcycles and probably vehicles for easy transportation at reduced costs. According to the results, female tomato farmers are more primitive in the use of simple farm tools than male tomato farmers. Fasina et al. (2005), reported that one of the serious problems affecting agricultural productivity in the tropical and developing countries like Nigeria is the effective use of local tools. High pest and disease infestation (66.3\%) $(62.2 \%)$, low market price $(63.9 \%)(59.5 \%)$ and high perishability of the commodity $(54.2 \%)(70.0 \%)$ were problems identified by both male and female tomato farmers, respectively in the study area.

Prevalence of pests and diseases such as late blight, nematodes and cutworms were the most important pests and diseases reported by nearly one half of the respondents. 
Female tomato farmers were more sensitive to the infestation of diseases and pests and probably carried out effective control before notable crop damages were recorded, which reflected in their ability to accrue higher market price than their male counterparts. In Nigeria, tomato has more disease and insect problems because the crop is prone to pests and diseases infestation, where soils have become exhausted by the need to produce more food for increasing populations and where fertilizers are hardly available and expensive for farmers. Ray et al. (2015) revealed that all forms of agriculture are threatened when resistance develop in plant pests. Adegbite et al. (2010), pointed out that as the cultivation area for tomato expands, pest and disease problems increase in severity. However, female tomato farmers recorded high perishability than male tomato farmers due to untimely arrival of tomato fruits to the market places because of lack of means of transportation. However, inadequate market facilities (56.8\%) and lack of storage facilities (64.9\%) were problems identified by the female tomato farmers in the study area. This may be due to the fact that most women in the study area do not own a house where they can store their produce. This implies that female tomato farmers spend more on storage cost than their male counterpart. Due to the perishable nature of tomato, farmers agreed that lack of storage facilities is a serious problem. Thus, adequate markets and storage facilities are needed to reduce losses and physical damages to the produce. This finding agrees with Usman and Bakari (2013) who confirmed poor storage facilities as the most serious problem encountered in the marketing of vegetable.

\section{Conclusion and Recommendations}

The findings of this study showed that majority of the farmers were within the active productive age bracket which is instrumental to their effectiveness in tomato production. Male and female farmers played prominent roles in tomato production with high number of male farmers. Tomato production was profitable to both male and female farmers in the study area. Inadequate capital, lack of contact with extension services, high cost of labour, high pest and disease infestation, high perishability of tomato fruits and others were the problems faced by the respondents in the study area. Female tomato farmers should be encouraged to cultivate improved crop varieties with strong seed coat and longer shelf life. The female tomato farmers could pool their resources together to purchase motorcycles or vehicles for easy movement of their produce from the farm gates to market places in order to reduce high perishability of tomato fruits. Also, female tomato farmers should endeavor to use farm machinery and herbicides to solve the problems of inadequate labour supply and use of simple farm tools respectively, which do not encourage large scale production. The male tomato farmers should control pests and diseases infestation, package their tomato fruits to make them more attractive to consumers in order to earn higher market price.

\section{CONFLICT OF INTEREST}

The authors declare that they have no conflict of interest.

\section{REFERENCES}

Abdullahi, M. R. (2012). Women in agriculture: The role of African women in agriculture. National Agricultural Extension and Research Liaison Service, Ahmadu Bello University, Zaria, Nigeria.

Adegbite, R. A., Dike, M. C., \& Akpa, A. D (2010). Preliminary studies on insect pests of green house tomato production in Northern Guinea Savanna of Nigeria. In: Entomology in Nigeria Building.

Adejobi, A. O., Babatunde, R. O., \& Idowu, E. O. (2011). Weight and measurement issues in retail marketing of fresh tomatoes: evidence from Osun State. Journal of Agricultural Science, 6(4), 20-26.

Adenugba, A. O., \& Raji- Mustapha, N. O. (2013). The role of women in promoting agricultural productivity and developing skills for improved quality of life in rural areas. IOSR Journal of Engineering, 3(8), 51-58.

Afolabi, M. M. (2008). Women as pillars of national economy in Nigeria: A study of economic activities of rural women in six local government areas of Ondo State. IAFFE Summer Conference, International Association for Feminist Economics, Torino, Italy, 19 June- 21 July 2008.

Akinsanmi, A., Doppler, W., \& Nwajiuba, C. (2005). Gender inequalities and their implications for living standard and food security among male and females-headed households in Imo state, Nigeria. Conference on International Agricultural research for development, October 11-13, Tropententag, Stuttgart-Hohenheim

Amali, E. (2009). The role of women in agricultural development process. Development Studies Review Centre Publication, University of Jos, Nigeria, 1 and 2: 52-60.

Audu, T. (2009). Gender dimensions of agriculture, poverty, nutrition and food security in Nigeria. Nigeria Strategy Support Programme (NSSP) Background Paper No. NSSP 005.IFPRI, Abuja, Nigeria. P. 40

Ayoola, J. B., \& Odiaka, E. C. (2004). Gender perspectives on Agricultural Development. Experience from Benue State of Nigeria. Proceeding of 38thAnnual Conference of ASN.

Dam, B. V., Goffau, M. D., Lidth de Jeude, J. V., \& Naika, S. (2005). Cultivation of tomato: Production, processing and marketing. Agromisa/CTA. Series no 17.

Damisa, M. A., \& Yohanna, M. (2007). Role of rural women in farm management decision making process: Orderedprobit analysis. Trends in Applied Science Research, 2(3), 241-145.

Fasina, A. S., Aruleba, J. O., Omolayo, F. O., Omotoso, S. O., \& Shittu, O. (2005). Evaluation of potential of some soil for crop production at Edo-Ekiti, South West Nigeria. Journal of Soil Science, 15(2), 77-78.

Food and Agricultural Organization (FAO) (2012). Growing greener cities in Africa. First status report on urban and peri- urban horticulture in Africa. Rome, Food and Agricultural Organization of the United Nations.

Food and Agricultural Organization (FAO) (2016). More fruits 
and vegetables.

Food and Agriculture Organisation (FAO) (2005). A synthesis report of the African Region: Women, agriculture and rural development. Report prepared under the auspices of FAO's Programme of Assistance in Support of Rural Women in Preparation for the Fourth World Conference of Women; Food and Agriculture Organization of the United Nations, Rome, Italy.

Food and Agriculture Organisation (FAO) (2010). Gender and land rights - Understanding complexities, adjusting policies; Economic and social perspectives, FAO Policy Brief, Rome: FAO.

Ibitoye, S. J., Shaibu, U. M., \& Omole, B. (2015). Analysis of Resource Use Efficiency in Tomato (Solanum lycopersicum) Production in Kogi State, Nigeria. Asian Journal of Agricultural Extension, Economics and Sociology, 6(4), 220-229.

Idyorough, A. E. (2005). Gender concepts and Issues in Nigeria. Aboki Publishers, Makurdi-Abuja-lbadan.

Kale, H., \& Derek, H. (2020). International Food Policy Research Institute (IFPRI) Blog: Research Report, May 4, 2020.

Lovendal, C. R., \& Knowles, M. (2006). Tomorrow's hunger: A framework for analysing vulnerability to food security. WIDER Working Paper Series RP2006-119, World Institute for Development Economic Research (UNU-WIDER).

Maurice, D. C. (2004). Resource production in cereals crop production among Fadama farmers of Adamawa State Nigeria. M.Sc. thesis, Department of Agricultural Economics and Extension, Federal University of Technology, Yola, Nigeria.

Mielgo-Ayuso, J., Aparicio-Ugarriza, R., Olza, J., ArancetaBartrina, J., Gil, Á., Ortega, R. M., Serra-Majem, L., VarelaMoreiras, G., \& González-Gross, M. (2018). Dietary Intake and Food Sources of Niacin, Riboflavin, Thiamin and Vitamin B6 in a Representative Sample of the Spanish Population. The ANIBES Study. Nutrients, 10(7), 846.

Ndaghu, J. N., Sallawu, H., \& Omojeso, B. V. (2015). Socioeconomic factors affecting adoption of innovations by cocoa farmers in Ondo State, Nigeria. European Journal of Business, Economics and Accountancy, 3(2), 58-66.

Nnadozie, B., \& Ibe, I. (2006). Women in agriculture: problems and prospects. In: Nwosu, A. C. Nwajuba, C. U., \& Mbanasor, J. A. (eds.). Agricultural Transformation in Nigeria. Novelty Industrial Enterprises, Owerri, Nigeria.

Obayelu, A. E., Arowolo, A. O., Ibrahim S. B., \& Croffie A. Q. (2014). Economics of fresh tomato marketing in Kosofe Local Government Area of Lagos State, Nigeria. Nigerian Journal of Agricultural Economics, 4(1), 58-67.

Olatona, F. A., Sosanya, A., Sholeye, O. O., Obrutu, O. E., \& Nnoaham, K. E. (2018). Knowledge of fruits and vegetables, consumption pattern and associated factors among adults in Lagos State, Nigeria. Research Journal of Health Sciences, 6(2), 50-62.

Olukosi, J. O., \& Erhabor, P. O. (2008). Introduction to farms management economic: Principals and applications. Agitab publishers Ltd., Zaria Nigeria, Pp. 1-92.

Onu, G. E. (2006). Meeting the challenges of rice demands through children and youth-in-agriculture. A paper presented at 10th Annual Conference of the National Research and Development, Network of Children and Youth-in-Agriculture Programme (CYIAP).
Ozor, N., \& Nnaji, C. (2010). Difficulties in adaptation to climate change by farmers in Enugu State, Nigeria. Journal of Agricultural Extension, 14(2), 106-122.

Rahman, S. A. (2008). Women's involvement in agriculture in northern and southern Kaduna State. Journal of Gender Studies, 17, 17-26.

Ray, D. K., Gerber, J. S., MacDonald, G. K., \& West, P. C. (2015). Climate variation explains a third of global crop yield variability. Nature Communications, 6(1), 1-9.

Sani, M. H., \& Haruna, U. (2010). Farm planning model for sustainable vegetable crop production in the Eastern part of Kogi State, Nigeria. Journal of Agronomy, 9(1), 17-22.

Saliu, O. J. \& Obasi, M. O. (2011). Inadequate fertilizer use for sustainable maize production by small scale farmers in Nigeria. Applied Tropical Agriculture, 16(1\&2), 79.

Sekumade, A. B., \& Toluwase, S. O. W. (2014). Profitability and production efficiency of indigenous tomato cultivation among farmers in Osun state, Nigeria. IOSR Journal of Agriculture and Veterinary Science, 7(11), 13-23

Shaw, J. B. (2004). Gender Inequalities and their implications for living standard and food security among male and femaleheaded households in Imo State, Nigeria. Conference on International Agricultural research for Development, October 11-13, Tropentag, Stuttgart- Hohenheim.

Shing-Jy, J. T., \& Hsiao-Feng, L. (2013). Handbook of Vegetable Preservation and Processing. Y. H. Hui, Y. H., Ghazala, S., Graham, D. M., Murrell, K. D., \& Nip, W-K. (eds.). CRC Press.

Teshone, H. A. (2019). The derivation and choice of appropriate test statistics ( $\mathrm{z}, \mathrm{t}, \mathrm{f}$ and chi- square test) in research methodology. Science Publishing Group Mathematics Letter, 5(3), 33-40.

Tiwani, A. A. (2010). Beneficiary impact assessment of the ADB Fadama development II in Kogi State, Nigeria. Submitted to National Fadama Coordination Office Abuja.

UNDP (2009). Resource guide on gender and climate change, New York: UNDP

Usman, J., \& Bakari, U. M. (2013). Profitability of small scale dry season tomato (Lycopersicon esculentum Mill.) production in Adamawa States, Nigeria. Journals of Science and Technology. 3(6), 25-39.

Varela, A. M., Seif, A., \& Lohr, B. (2003). A guide to IPM in tomato production

Eastern and Southern Africa. CTA/ICIPE/GTZ.

Verter, N., \& Bečvářová, V. (2014). Yam production as a pillar of food security in Logo Local Government Area of Benue State, Nigeria. European Scientific Journal, 10(31), 27-42.

World Bank (2003). Nigeria: Women in agriculture, In: Sharing experiences-Examples of participating approaches. The World Bank Group. The World Bank Participating Sourcebook, Washington, D. C. Retrieved from http:/www.worldbank.org/wbi/publications.html. 